\title{
鈴鹿山脈東麓地域の第四紀における変形速度
}

\author{
京都大学大学院理学研究科地球惑星科学専攻* 石 山達也・竹 村 恵二 \\ 岡田篤正
}

\section{Structural Growth Rate of the Eastern Margin of the Suzuka Range during Quaternary}

\author{
Tatsuya Ishiy ama, Keiji Takemura and Atsumasa OKada \\ Division of Earth and Planetary Science, Graduate School of Science, Kyoto University, \\ Kitashirakawa-oiwake-cho, Sakyo-ku, Kyoto 606-8502, Japan
}

(Received October 15, 1998; Accepted June 23, 1999)

\begin{abstract}
A seismic reflection profile implies that foothills and terrace surfaces in the eastern margin of the Suzuka Range are underlain by an east-facing monocline. Based on the stratigraphy of the late Pliocene-middle Pleistocene Tokai Group and a drill core of $500 \mathrm{~m}$ deep, we correlated distinct seismic reflectors to the boundaries between the Komeno Formation and the Oizumi Formation of the Tokai Group. Analysis of growth strata demonstrates that monoclinal uplift of the Tokai Group and Paleozoic rocks began since the beginning of the deposition of the lowermost part of the Tokai Group (ca. 3.0 Ma). Total vertical growth and shortening of the bottom of the Tokai Group during the deposition of the growth strata are estimated to more than $1,800 \mathrm{~m}$ and $1,000 \mathrm{~m}$, respectively. Using an age of $2.9 \pm 0.2 \mathrm{Ma}$ for the Ichinohara volcanic ash, which overlies near the bottom of the Tokai Group, based on fission track method, uplift rate since late Pliocene is $>0.58-0.68 \mathrm{~mm} / \mathrm{yr}$, and horizontal shortening rate is $>0.30-0.37 \mathrm{~mm} / \mathrm{yr}$. The resulting long-term structural grow th rates are comparable to those of the Fumotomura fault during late Quaternary based on previous geomorphic studies, which suggests that the Fumotomura fault is responsible for the growth of the monocline. If so, the fact that terraces are deformed more narrowly than the Tokai Group implies that the monocline and the warping of terrace surfaces is fault-propagation fold.
\end{abstract}

Key words: Suzuka Range, Fumotomura fault, Seismic reflection profile, Structural growth rate, Fault-propagation fold.

§1.はじめに

鈴鹿山脈は近畿三角帯 [HuZITA (1962)] の北東縁部に 位置する南北方向の細長い山脈である．その両側の低地 には鮮新一更新統の東海層群や古琵琶湖層群が厚く堆積 し，その上位に新旧の段丘堆積物が広く覆って分布す る. 山脈の両側には南北走向の逆断層が存在し，その活 動によって第四紀における山脈の著しい隆起が生じたと される．特に鈴鹿山脈東麓部では逆断層の一部が第四紀 後期以降も活動を継続していることが知られている [武 久 (1979), IKEDA (1983), 太田・寒川 (1984), 鈴木・他 (1996); Fig. 1].

\footnotetext{
* \%606-8502 京都市左京区北白川追分町
}

近畿三角帯には南北走向の逆断首が数多く存在する [活断層研究会 (1991)]。この地域は第四紀以降東西圧縮 の場にあるとされ [HuZITA (1962)]，上部地壳の歪みの 解放・蓄積の過程には鈴鹿山脈東麓部の活断層に代表さ れる南北走向の逆断首の活動が寄与している．第四紀に おける近畿三角帯の短縮テクトニクスを理解する上で, 南北走向の逆断層の水平短縮量を見積もることは重要な 研究課題である. 従来はおあに地形学的手法により逆断 層の平均上下変位速度が求められているが [活断層研究 会 (1991)]，断層運動に伴う水平短縮成分は求められて いない，また，低角逆断層の場合上下変位量に比べて水 平短縮量が大きくなるので, ネットスリップを知る上で も水平短縮量を評価することは重要である. 


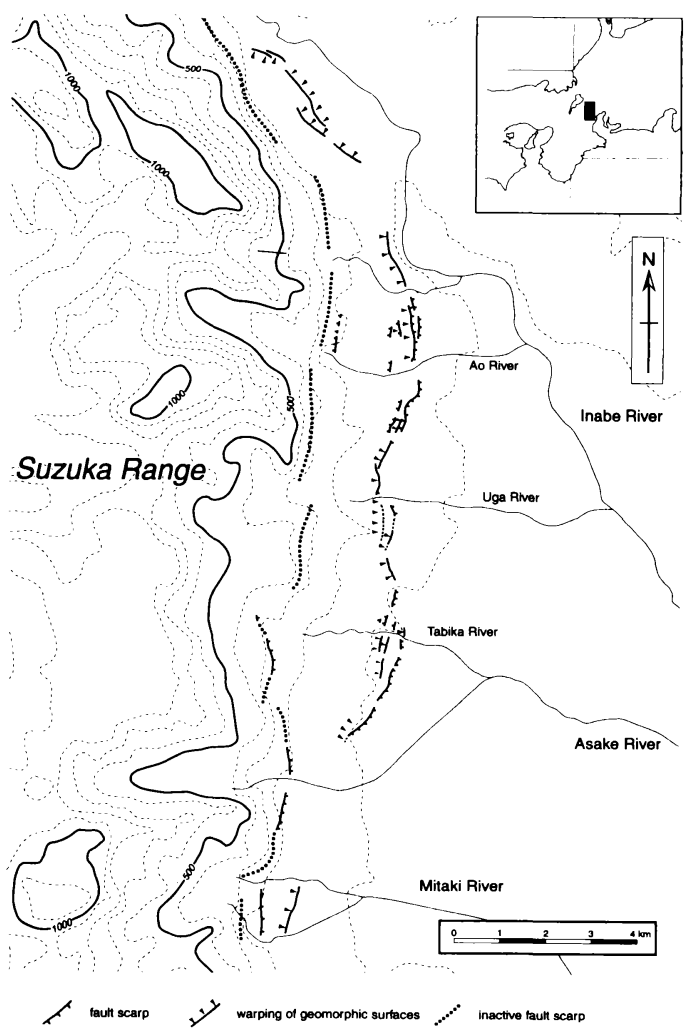

Fig. 1. Summit level map of the eastern margin of the Suzuka Range showing the surface traces of active faults.

ボーリングや反射法地震探査などの地下構造データが ある場合, 推定される地下断面を利用して地層の上下 落差量・水平短縮量を求めることが可能である. 地下 構造から地層の変形構造の成長を示す growth strata [SuPPE et al. (1992)] を認定し, その堆積年代から成長速 度を推定する手法は Transverse Ranges [HuFTILE and YEATS (1995)] などの地域で採用されている．鈴鹿山脈 東麓部では, 活断層を横断する測線で反射法地震探查が 実施された[三重県地域活断層調查委員会 (1996)] ほか, 反射測線上の北勢町麓村で地質調查所が到達 深度 $500 \mathrm{~m}$ のボーリングを掘削しており[佐藤・他 (1999)], 地質構造とその成長速度を推定するのに適し た地域であるといえる.

本論では，上記の地下構造データを利用して鈴鹿山脈 東麓部の地質構造を推定し, 本地域の平均変形速度を求 めた. また, 空中写真判読と現地調查によって再検討し た変位地形の分布・性状を地質構造と比較し, 第四紀に おける鈴鹿山脈東麓部の断層運動に伴う地形・地質構造 の発達過程を推定した.

\section{§ 2. 地形・地質概説}

鈴鹿山脈は最大標高 $1,241 \mathrm{~m}$ を有し, 幅約 $20 \mathrm{~km} ・$ 長さ約 $50 \mathrm{~km}$ で細長く南北に延びる．この山脈は大局 的には東部が高く西に緩やかに下がる非対称な形を有 し，分水界も著しく東に偏っている。

反射法地震探査測線周辺の地質図を Fig. 2 に示す. 鈴 鹿山脈は, 砂岩・石灰岩・チャートなどからなる中・古 生界および白亜紀末に貫入した花岡岩からなる［原山・ 他 (1989)].

鈴鹿山脈の東斜面は比高数 $100 \mathrm{~m}$ の急崖をなし，そ の東麓部には標高約 $300 \mathrm{~m}$ 以下の丘陵・段丘が広がる.

丘陵を構成する鮮新一更新統の東海層群の層相・層序 については, TAKEMURA (1985) や吉田 (1990) による詳 しい研究がある. それらによると, 本地域の東海層群は 陸成（河成および湖沼成）堆積物であり, 下位から美 鹿・古野・市之原（あるいは多志田川）・大泉・米野の 各累層に区分できる. 当地域の東海層群の堆積年代は, 各累層に挟まれるテフラのフィッション・トラック年代 からおよそ $3.0 \mathrm{Ma}$ から $1.2 \mathrm{Ma}$ の間と推定されている (Fig. 3).

東海層群とそれ以前の地層である中・古生界, 花岡岩 あるいは中新統は地表で観察される限り断層関係にある ことが知られ, 西傾斜の高角逆断層露頭が多数認められ ている [例えば, 秦 (1967)]. 従来, この断層は一志断層 と呼ばれている [例えば, 滝本(1935)]. 今回取り上げる 地域では少なくとも地表部には中新統は分布しておら ず，一志断層は先新第三系と鮮新一更新統を境する.

本地域では, 丘陵を構成する東海層群を不整合に覆っ て扇状地性の段丘面群が発達している［竹原・木村 (1962), 太田・寒川 (1984)]. 空中写真判読および現地 調查により作成した本地域の地形分類図を Fig. 4 に示 す. 段丘面群は, 地形面の広がり - 分布高度 - 開析度 連続性・比高および堆積物の風化度などにより, 高位 2 面 $(\mathrm{H} 1 \cdot \mathrm{H} 2)$ ・ 中位 2 面 $(\mathrm{M} 1 \cdot \mathrm{M} 2)$ ・低位 2 面 $(\mathrm{L} 1 \cdot \mathrm{L} 2)$ の 計 6 面に分類できる. ただし, 場所によってはさらに細 分することが可能である. 本論の段丘面分類は太田・寒 川 (1984)による分類に準ずる.

本地域では段丘堆積物中に第四紀後期に降下した火山 灰層はほとんど見出せず，広域テフラによる段丘面の形 成年代の編年を行うことは困難である. 木村 (1971) は, 伊勢平野に分布する段丘面の形成に関する研究を行い, 最終間水期の海進時に堆積したと考えられる海成粘土層 を中位段丘砅層 (M2 面構成層に相当) が覆うことから， 中位段丘面 (M2 面相当) を下末吉面に対比している. 太 田・寒川 (1984) は他地域の下末吉相当面に比べて M2 面の保存が良いことから, 若干新しい形成年代 (約 5 8 


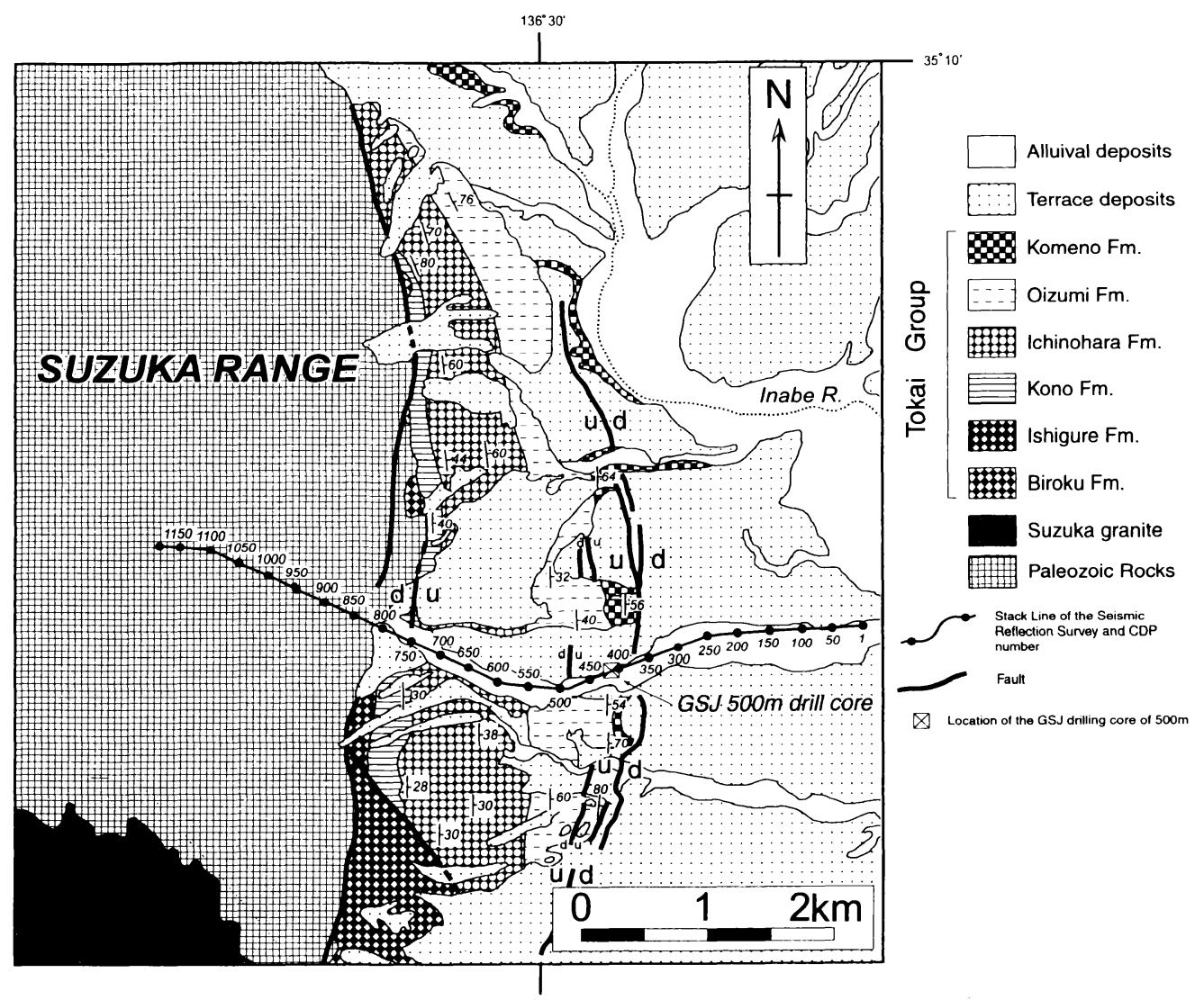

Fig. 2. Geological map of the eastern margin of the Suzuka Range [after Haray AmA et al. (1989) and Yoshida et al. (1991)]. Seismic reflection survey line (stack line) and location of drill core of $500 \mathrm{~m}$ are also shown.

万年) を推定している.

北勢町別常名では, M2 段丘面の構成層の上位に層厚 約 $3 \mathrm{~m}$ の細粒堆積物がのっている. この細粒堆積物から $10 \mathrm{~cm}$ おきに試料を採取して火山灰分析を行ったとこ 万, 鬼界アカホヤ火山灰 [町田・新井 (1978): $6.3 \mathrm{ka}$ ～と 姶良 Tn 火山灰 [町田・新井 (1976): 2.1 2.5 ka] に由 来すると推定される火山ガラスが見出された．細粒堆積 物は無層理であり，砂をほとんど含まないことから，段 丘面離水後に堆積した風成堆積物が風化したあのである と考えられる [片岡・吉川 (1997)]. したがって, M2 面 はこれらの火山灰の降灰年代以前に形成されたと推定さ れる. また, L1 面構成首からは, 放射性炭素年代測定に

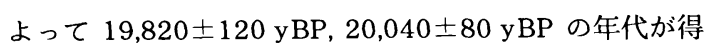
られており [三重県地域活断層調查委員会 (1996)], L1 段丘面は最終水期後期に形成された扇状地性の段丘面で あると推定される。

\section{§ 3. 鈴鹿山脈東麓部の活断層の分布と性状}

地質構造と断首運動による変位地形を比較するため に, 米軍撮影約 1 万分の 1 空中写真の判読および現地調 査による变位地形の検討を行った。

\section{1) 概説}

本地域の活断首の分布を Fig. 4 にまとめた.

鈴鹿山脈之丘陵・台地の境界を区切る山麓線に沿って は比高数 $100 \mathrm{~m}$ 以上に達する急崖が存在し, これら は断層崖であると認定できる。このうち藤原岳断層 [太 田・寒川 (1984)］は段丘面を変位させておらず，第四紀 後期に活動的である証拠はない（位置は Fig. 4 に示す）. 一方, 尾高断首・称野断層 [太田・寒川 (1984)] は高 位・中位・低位段丘面を変位させており (Fig. 4), 第四 紀後期を通じて活動的であることは間違いない. 藤原岳 断層・尾高断層の位置は地質学的に認められる一志断層 の位置とほぼ一致する.

山麓線に沿って分布する活断層より $2 \sim 3 \mathrm{~km}$ 東には 段丘面を变位させる低断首崖・撓曲崖が約 $11 \mathrm{~km}$ 連続 


\section{thickness $(m)$}

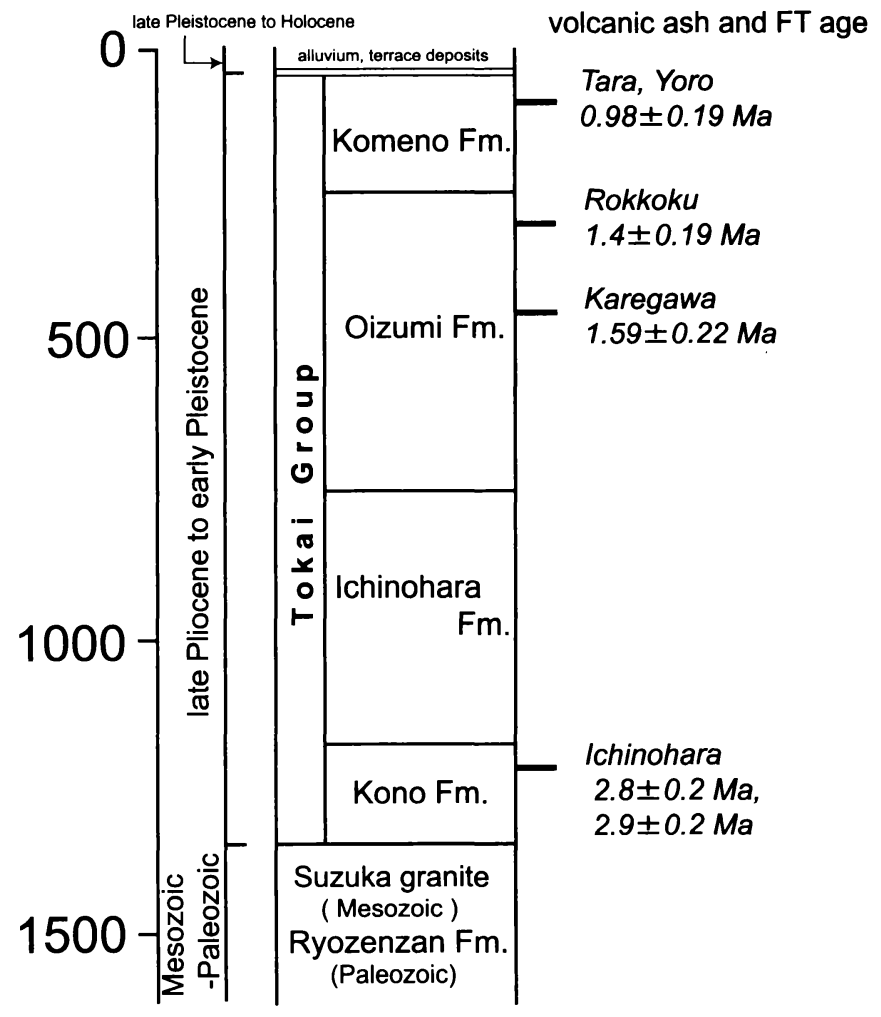

Fig. 3. Stratigraphic column in the eastern margin of the Suzuka Range [after TAKEMura (1984) and Yoshida et al. (1991)].

する. 太田・寒川 (1984) はこれらを一括して麓村断層 と命名した，麓村断層に沿っては丘陵背面にのる高位段 丘面が東に撓曲変形しているほか, 中位・低位段丘面上 に低断層崖・撓曲崖が認められる，また，宇賀川右岸で は沖積面を変位させる低断層崖が認められる。

藤原岳断首之麓村断層にはさまれた丘陵部には，段丘 面上に西落ちの逆向き低断層崖・撓曲崖が分布する。こ のうち, 据榑北山断首 [太田・寒川 (1984)]については 段丘構成層を変形させる高角逆断層露頭が報告され，こ れは層面すべり断層とされている [東郷・岡田 (1989)]. また, 新町断層は藤原岳断層の $300 \mathrm{~m}$ 東に位置する非 常に明瞭な低断層崖である。このほかにも，宇賀川右岸 加田光川左岸の丘陵背面にのる段丘面上に西落ちの逆 向き低断層崖が存在する。これら逆向き低断層崖の平均 上下変位速度は簏村断層に比べて小さく [太田・寒川 (1984), 東郷・岡田 (1989)], 断層線の長さむ $1 \mathrm{~km}$ 未満 之短いことから副次的な活断首であると考えられる。

本地域の活断層は, その性状から, (1)山麓線沿いに分 布する藤原岳断層・尾高断首・荍野断層, (2)(1)上り2 $3 \mathrm{~km}$ 東に分布する麓村断層, (3)丘陵部に分布する石榑
北山断層・新町断層などの副次的な活断層群, に分類で きょう. 上述のとおり, 藤原岳断層については第四紀後 期に活動的である証拠はない，藤原岳断層より平野側に 第四紀後期を通じて活動的な麓村断層が分布すること は, 断層の活動性が第四紀後期に平野側に移動したこと を示唆する [IKEDA (1983), 太田・寒川 (1984)].

2) 反射測線付近の変位地形

反射法地震探査測線付近の変位地形を Fig. 5 に示す. この地域では撓曲崖上の高位段丘面群が東西方向で約 $500 \mathrm{~m}$ の幅をむって東に撓み下がる.この撓曲崖に連続 して M2 段丘面上に東落ちの撓曲崖が存在する. 撓曲変 形する高位段丘面 $(\mathrm{H} 1)$ は石榑北山断層によって変位を 受けているが, その量は麓村断層による変位量に比べて はるかに小さい，また，高位段丘面群を変位させる撓曲 崖から $100 \mathrm{~m}$ ほど東には M2 段丘面を切る東落ちの低 断層崖が約 $500 \mathrm{~m}$ にわたって連続する.このことは, 麓 村断層の活動が第四紀後期を通じて平野側に移動してい ることを示唆する. 


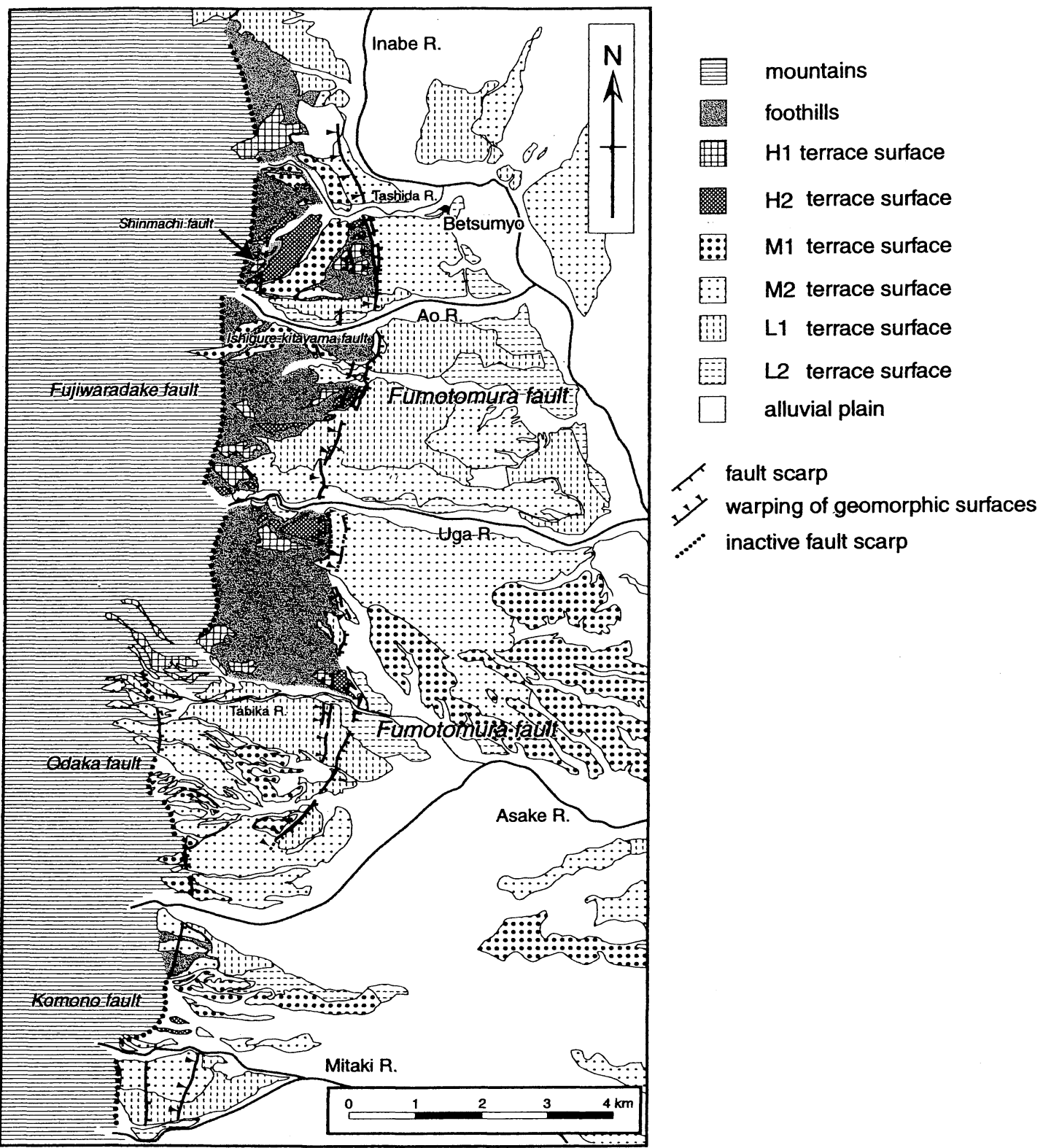

Fig. 4. Geomorphologic map showing surface traces of active faults.

\section{§4. 反射断面から推定される鈴鹿山脈東簏部の地質} 構造

麓村断層と藤原岳断層の間の丘陵部では, 東海層群が 東におよそ 30 度から 40 度でほぼ一様に傾斜する様子 が地表で連続的に観察できる (Fig. 2).

このような東海層群の地質構造と断層運動の関係につ いては打あに 2 つの説明がされている。 ひとつは，段丘 面の傾斜が東海層群の傾斜に比べて小さいことから, 東 海層群の変形と撓曲崖を形成するような麓村断層による
変形が調和的であるとする考えである [太田・寒川 (1984)]. また，低角逆断層の運動により上盤側先端部で 背斜状の变形が進行し, 逆向き低断層もこの変形によっ て形成されたと推定されている [IKEDA (1983)].

これに対して, 東郷・岡田 (1989) は東海層群が麓村 断層の上盤側で一様に東に傾斜し, 低角逆断層の活動に 伴う背斜あるいは撓曲崖をつくるような変形と調和して いないことを指摘している，そして，東海層群の変形は 麓村断層が活動を開始する以前に藤原岳断層の活動に 


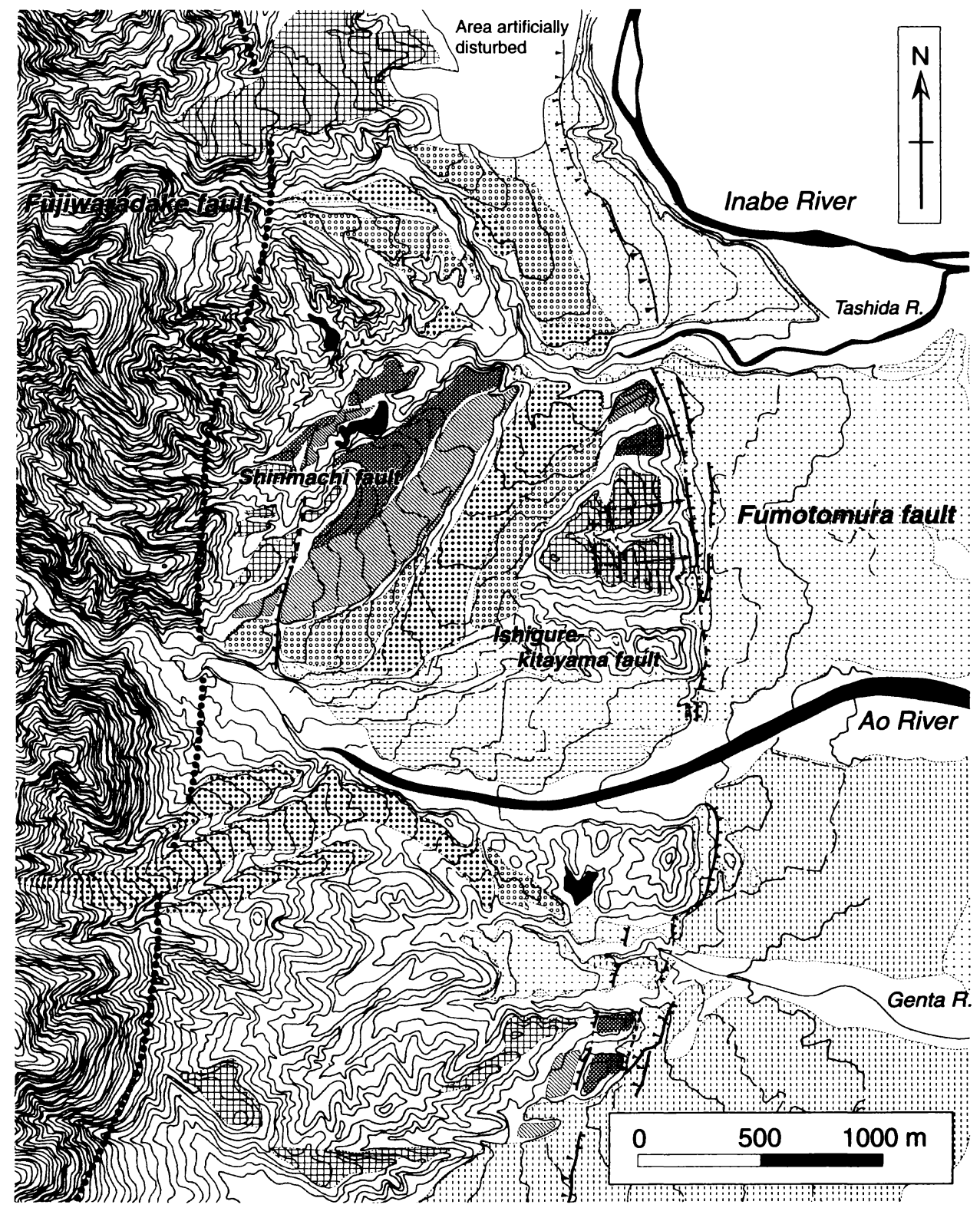

\section{L fault scarp $y^{\prime}$ warping of geomorphic surfaces $\because \because$ inactive fault scarp} 嘈 H1 H2 $\mathrm{H}$ H2I

Fig. 5. Late Quaternary deformation showing precise location of surface traces of active faults.

よって形成されたとしている [東郷・岡田 (1989)].

これらの説明は, 地表面付近における東海層群と段丘 面の変形の比較に基づいている. しかし, 麓村断層・藤 原岳断層の活動之東海層群の地質構造の関係を論ずるた めには, 丘陵の幅と同程度の深さ方向の地下構造に関す る情報が必要である.
鈴鹿山脈東麓部では, 三重県員弁郡北勢町において麓 村断層・藤原岳断層を横切る測線で反射法地震探查が実 施されている [三重県地域活断層調査委員会 (1996)]. また，本測線上では麓村断層を貫くボーリングが実施さ れている [佐藤・他 (1999)]. 本章では断層運動と東海 層群の地質構造の関係を明らかにするために, 反射断面 
とボーリングおよび表層地質のデータを対比し，鈴鹿山 脈東麓部の地質構造を推定した.

1) 反射断面の解釈

三重県地域活断層調查委員会 (1996) による反射法地 震探査の探查諸元を Table 1 に示す. 本探查は 1996 年 11 月に青川に沿った測線で実施された (Fig. 2)。測線長 は約 $6.5 \mathrm{~km}$ である.

時間断面 (Fig. 6a) を概観すると, CDP No. 370 付近 に反射面の不連続がみられるほか, CDP No. 370 から 800 にかけて反射面が東に傾斜することがわかる. ま た, CDP No. 5 から 370 にかけて反射面は緩く西に傾斜 する．また，麓村断層と藤原岳断層は，地表ではそれぞ れ CDP No. 370 と CDP No. 810 に位置する.

竹村・他 (1999)によれば, 反射面の連続性・明瞭 さ・P 波速度構造から，CDP No. 50 の $1.0 \mathrm{sec}$ から西に 延びる反射面と CDP No. $550,0.7 \mathrm{sec}$ から東に傾き下 がる反射面は東海層群と先新第三系の地質境界であると 考えられる. CDP No. 550, $0.7 \mathrm{sec}$ の反射面の地表面へ の延長部は中古生界と東海層群の地質境界にほぼ一致す る.

また，CDP No. 810 より東では，連続性が良く明瞭な 反射面が数枚確認できる。これらの反射面が不連続にな る領域は $1.0 \mathrm{sec}$ 付近まで幅 $100 \mathrm{~m}$ ほどの狭い範囲に限 定される，地表における断層線の位置を考慮すると，麓

Table 1. Recording parameters for the seismic reflection survey [after RESEARCH COMMITtee for Active Fault in Mie Prefecture (1996)].

\begin{tabular}{ll}
\hline Geophones resonant frequency & $8 \mathrm{~Hz}$ \\
Geophones / station & 9 \\
Station spacing & $10 \mathrm{~m}$ \\
Channels & 240 \\
Source & IVI Y-2400 \\
Near trace offset & $20 \mathrm{~m}$ \\
Sweep frequency & $10-80 \mathrm{~Hz}$ \\
Stacks & $8-12$ \\
Recording time & $5 \mathrm{~s}$ \\
Sampling interval & $2 \mathrm{~ms}$ \\
Recording filters & $8 \mathrm{~Hz}$ for low cut \\
CMP folds & $180 \mathrm{~Hz}$ for high cut \\
Survey line & 60 \\
\hline
\end{tabular}

村断層はこの範囲を通ると推定される.

2) ボーリングコアの層序

1997 年 9 月, 地質調查所は北勢町麓村の青川左岸で 到達深度 $500 \mathrm{~m}$ のボーリングを掘削した. その掘削位 置は反射法地震探查の測線上に位置しており (Fig. 2),

麓村断層を上盤側から下盤側へと貫いている [佐藤・他 (1999)].

石山・他 (1999) は, 岩相記載・火山灰試料分析・花 粉分析の結果に基づき, 本ボーリングコアの層序を推 定した (Fig. 7). それによれば, 深度 $10.15 \sim 76.65 \mathrm{~m}$

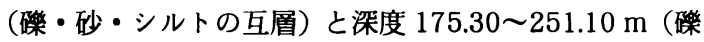
層が主体）が東海層群最上部の米野累層, 深度 76.65 $175.30 \mathrm{~m}$ と深度 $251.10 \mathrm{~m}$ 以深（シルト・粘土・砂の 互層）が大泉累層である. 深度 175.30 251.10 m の米 野累層之 76.65 175.30 m の大泉累層は断層関係にあ ると考えられる.

3） 反射断面・ボーリングコア・表層地質の対比から 推定される地質構造

反射断面・ボーリングコア・表層地質の対比に基づく 解釈断面図を Fig. $6 \mathrm{~b}$ に示す. 本地域の東海層群の積 算層厚は約 $1,500 \mathrm{~m}$ 之見積もられており [原山・他 (1989)], Fig. 6b からも東海層群はそれに準ずる層厚を 有することがわかる.

ボーリングコアにおける米野累層と大泉累層の地層境 界の位置は, 深度断面において連続性が良く, 強い反射 面 A· $\mathrm{A}^{\prime}$ (Fig. 6b) に一致する.この強い反射面は, 深度 $76.65 \mathrm{~m}$ より約 $8 \mathrm{~m}$ 連続するシルト・粘土首とその直 上に約 $6 \mathrm{~m}$ 連続する碰層の間の音響インピーダンス差 に対応すると考えられる. また, 反射面 $\mathrm{A}^{\prime}$ の連続を地 表部へ追跡すると, 米野累層が大泉累層の上位に整合で のる露頭の位置 [吉田・他 (1991); 吉田, 私信]にほぼ一 致する (Fig. 2).

コアの深度 $76.65 \mathrm{~m}$ より上の部分は喽層が卓越し, こ れに対応して反射面 $\mathrm{A} \cdot \mathrm{A}^{\prime}$ より上では反射面が不連続か つ不明瞭である. また, コアの深度 $76.65 \mathrm{~m}$ より下では シルト・粘土・砂の互層が卓越するのに対応して, 深度 断面上では反射面 $\mathrm{A} \cdot \mathrm{A}^{\prime}$ より下に連続性が良く強い反射 面が存在し, コア中の礫層と粘土層の境界あるいは砂層 と粘土層の境界に一致する.このように, 深度断面の反 射面 $\mathrm{A} \cdot \mathrm{A}^{\prime}$ はコア中で推定された大泉累層と米野累層の 地質境界の位置と一致し, さらにコア中の層相変化から 推定される反射面と実際に得られた反射断面は良く対応 している. したがって, 反射面 $\mathrm{A} \cdot \mathrm{A}^{\prime}$ は米野累層と大泉 累層の境界部であると考えられる.

Fig. 6b は, 鈴鹿山脈東麓の丘陵部には東海層群の単 斜構造が存在することを示す. 単斜東翼部の東海層群は 
W

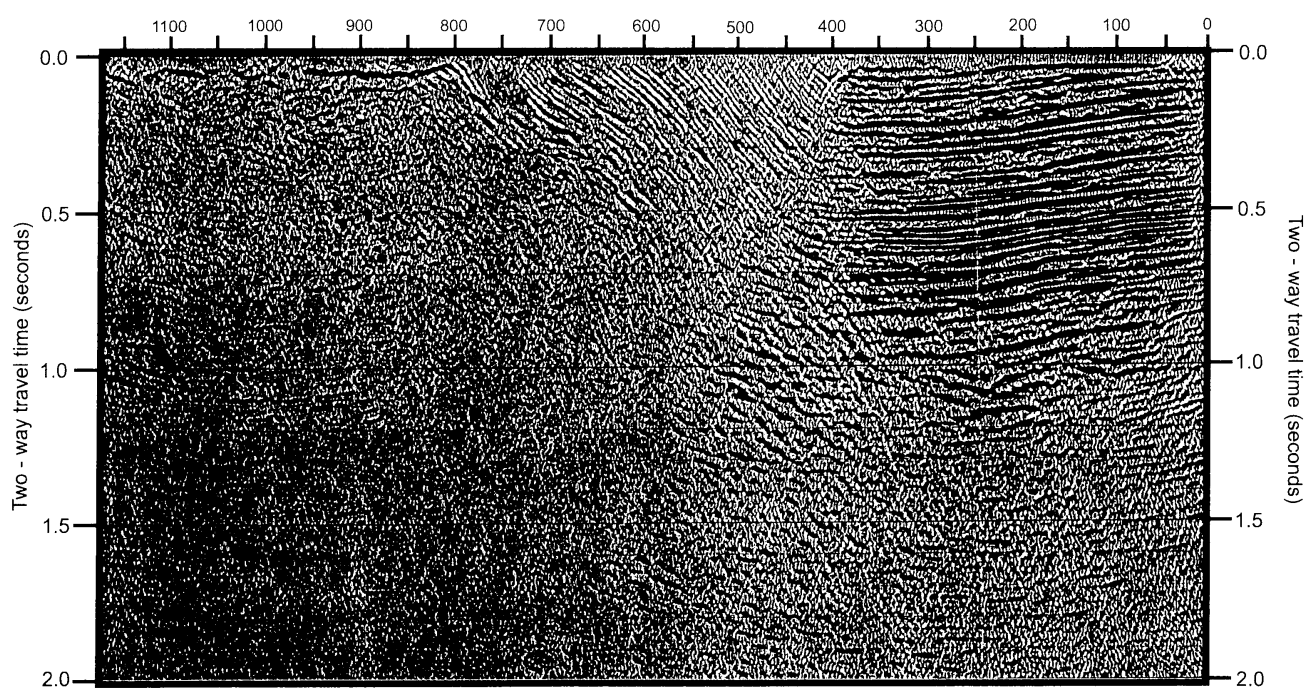

0

$1 \mathrm{~km}$

Fig. 6a. Uninterpreted seismic reflection profile (migrated, two-way travel time). Location on Fig. 2.

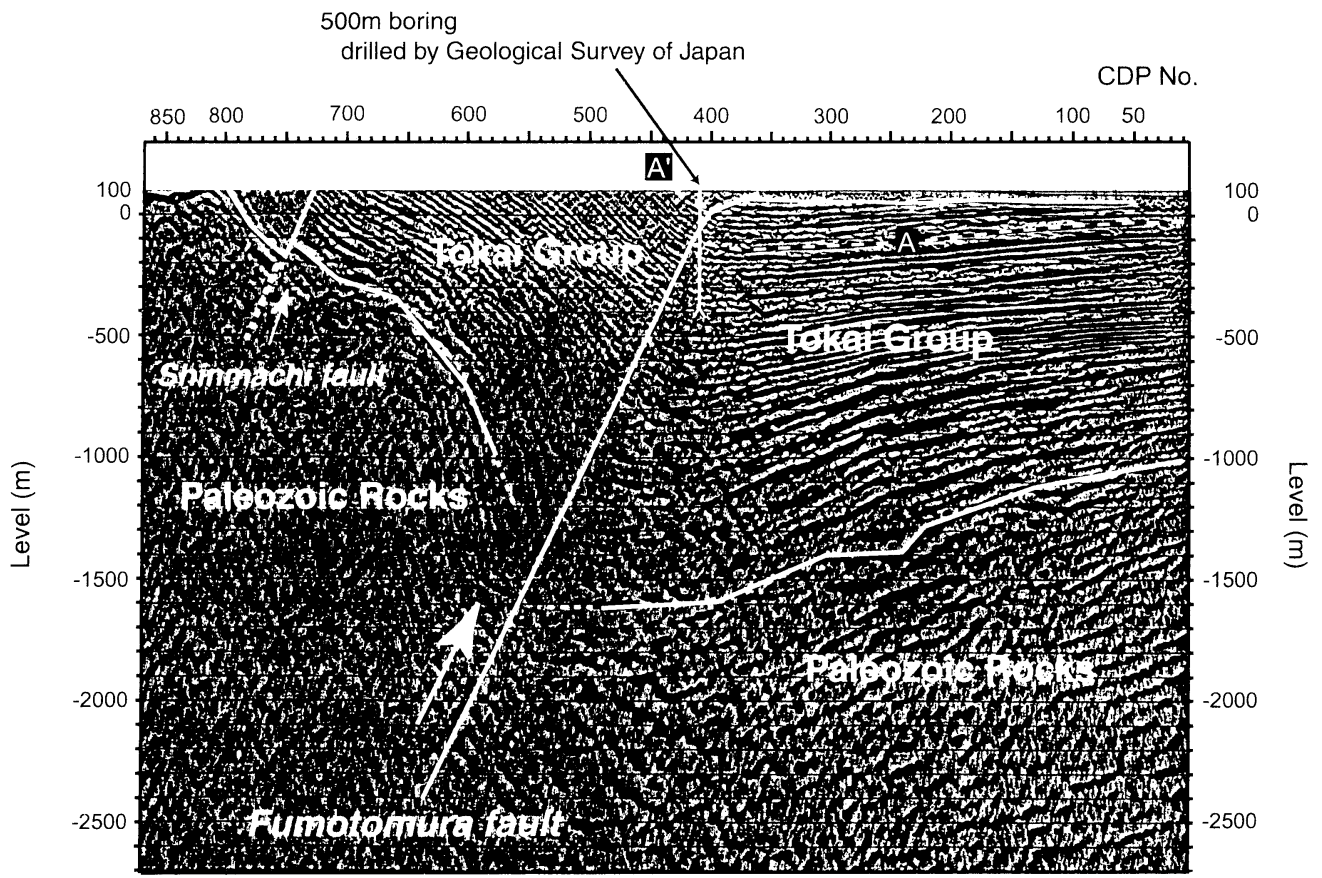

0

$1 \mathrm{~km}$

Fig. 6b. Interpreted seismic reflection profile (migrated, depth). Dashed lines (A and $A^{\prime}$ ) show the bottom of the Komeno Formation. No vertical exaggeration. 
Depth (m)

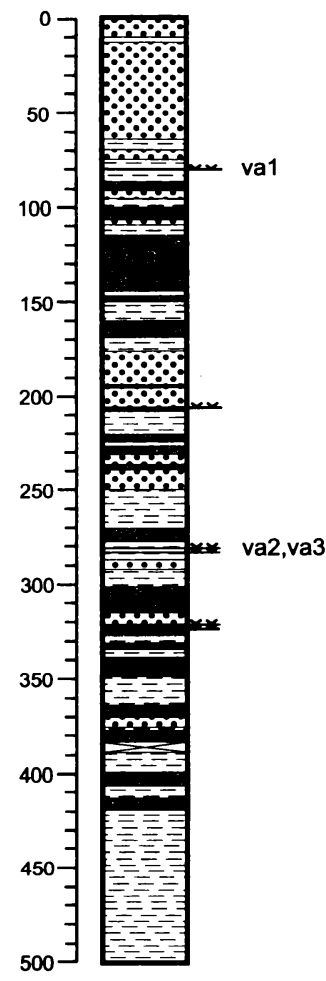

$\because \because 6$ gravel sand

\section{ve volcanic ash}

Fig. 7. Stratigraphy of boring core of $500 \mathrm{~m}$ deep drilled by Geological Survey of Japan. val can be correlated to Rokkoku volcanic ash. va2 and va3 can be correlated to Karegawa volcanic ash [after IsHiy Ama et al. (1999)]. Location on Fig. 2.

30 度から 40 度で一様に傾斜しており，地表で観察され る傾斜と良く一致する. 単斜東翼部は地下で折れ曲がる 軸を有しており, 麓村断首はこの単斜軸付近で単斜構造 を切っている.

簏村断層の傾斜は標高 $0 \mathrm{~m}$ 以上では低角であるが，そ れ以深では高角になる (Fig. 6b)。 また, 石榑北山断層は 地表では CDP No. 420 付近に位置するが，これに対応 する東海層群の变形は認められない，このことは石榑北 山断層が東海層群中に形成された副次的な断層であるこ とを示しており，この断首が層面すべり断層であるとす る報告 [東郷・岡田 (1989)] と整合的である. また，新 町断層が地表で確認される CDP No. 750 付近では先新 第三系之東海層群の地質境界に対応する反射面に西落ち の上下落差が認められるが, その変位量は小さいことか
ら新町断層あまた副次的な断層であると推定される．新 町断層は東に急傾斜する先新第三系と東海層群の地質境 界を切っていることから，局所的な伸張応力によって生 じた正断層であり，いわゆる bending-moment fault [YEATS (1986)] にあたると考えられる.

藤原岳断首は地表では Fig. 6b の CDP No. 820 付近 を通るが，これに伴う構造は反射断面では確認できな い.このことから，藤原岳断層の断首崖地形は，固結し た中古生界とやや固結した鮮新一更新統の地首境界部に 形成された差別侵食による組織地形である可能性があ る.

また，反射断面からは藤原岳断首から延びるスラスト により生じると期待される背斜は認められず，断層の傾 斜が低角である範囲は地下浅部に限定される。このこと は，本地域の逆断首の活動史が IKEDA (1983)による thrust-front migration では説明できないことを示す.

\section{§5. 考察

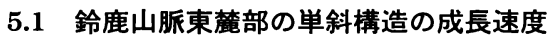

単斜構造に参加する東海層群の層厚変化をみると, 米 野累層より下位の東海首群の首厚は CDP No. 50 では約 1,000 m, CDP No. 350 では約 $1,200 \mathrm{~m}$ 之, 西方に徐々 に増大し, 単斜軸付近で約 $2,000 \mathrm{~m}$ と最大になる. 単斜 東翼部では反射断面で判断する限り東海首群の首厚は $1,700 \mathrm{~m}$ 程度である. 単斜東翼部の大部分は侵食によっ て消失しており，東海層群の層厚を正確に見積もること は困難であるが，単斜東翼部において東海層群の傾斜が ほぼ一定であることから，単斜軸以西の東海層群の首厚 はほとんど変化しないと考えて良いであろう。一方，麓 村断首下盤側における東海首群最上部・米野累首の首厚 は, 反射断面とボーリングコアから最大で $200 \mathrm{~m}$ 程度 と見積あられ (Fig. 6b)，単斜東翼部で地表において確認 された米野累層の層厚 [吉田・他(1991)］とおおよそ一 致する.このことから，単斜東翼部は大規模な侵食を受 けているものの，単斜軸部と同じ累首が保存されている と考えられる。したがって, 東海層群全体の層厚は単斜 軸部で最大になり，単斜東翼部では単斜軸部よりも首厚 を減じ，西方にほぼ一定の層厚を保っていたとみられ ろ.

Fig. $6 \mathrm{~b}$ から，この地域では大規模な上下落差と水平 短縮が生じていることがわかる．東海層群中の反射面は 麓村断層の両側で先新第三系上面の反射面と平行である から, 東海層群は水平にもともと堆積したと考えられ る. pre-growth strata の層理の長さが変形の前後で一 定であると仮定すれば, pre-growth strata の首理の長 さから上下落差量・水平短縮量を推定することができる 
[SCHNEIDER et al. (1996); Fig. 8]. 新町断層による小さい 変形量を無視したとき, Fig. 4b に含まれる範囲におけ る東海層群基底面の上下落差量および水平短縮量はそれ ぞれ約 $1,800 \mathrm{~m}, 1,000 \mathrm{~m}$ である. ただし, 単斜構造の東 翼部は大規模な侵食を受けて消失しているため, 実際の 変形量はこれらの值より大きいと考えられる，本地域の 東海層群の堆積開始時期は, 東海層群基底面直上に挟ま れる市之原火山灰のフィッション・トラック年代から,
$2.9 \pm 0.2 \mathrm{Ma}$ 前後であるとされる [横山・他 (1980)].こ の年代值と上記の変形量加ら求めた平均上下落差速度は $0.58 \sim 0.67 \mathrm{~mm} / \mathrm{yr}$ 以上, 平均水平短縮速度は $0.30 \sim$ $0.37 \mathrm{~mm} / \mathrm{yr}$ 以上となる.

\section{2 単斜構造の成長と活断層の関係}

反射断面之段丘縦断面を用いて東海層群の単斜構造と 段丘面の変形域の比較を試みる. Fig. 9 によれば東海層 群の単斜構造の範囲は東西 $3.8 \mathrm{~km}$ 以上におよぶ. 一方,

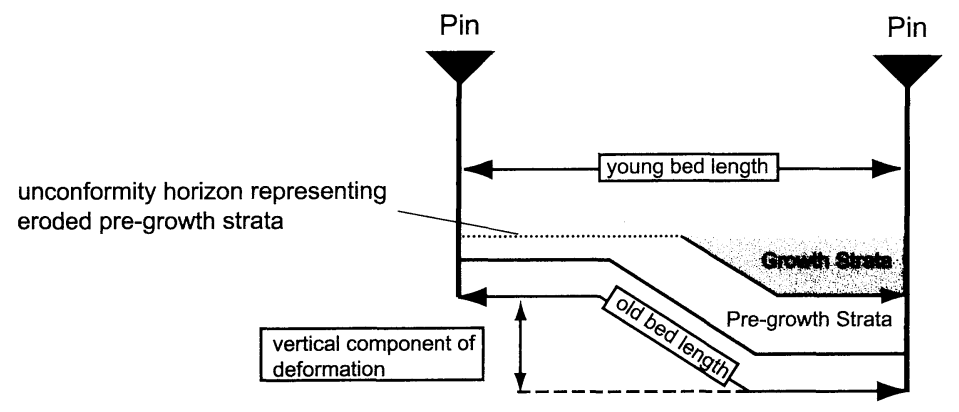

horizontal shortening = old bed length - young bed length

Fig. 8. Calculation of the vertical and horizontal component of structural growth from SchNeIDER et al. (1996).

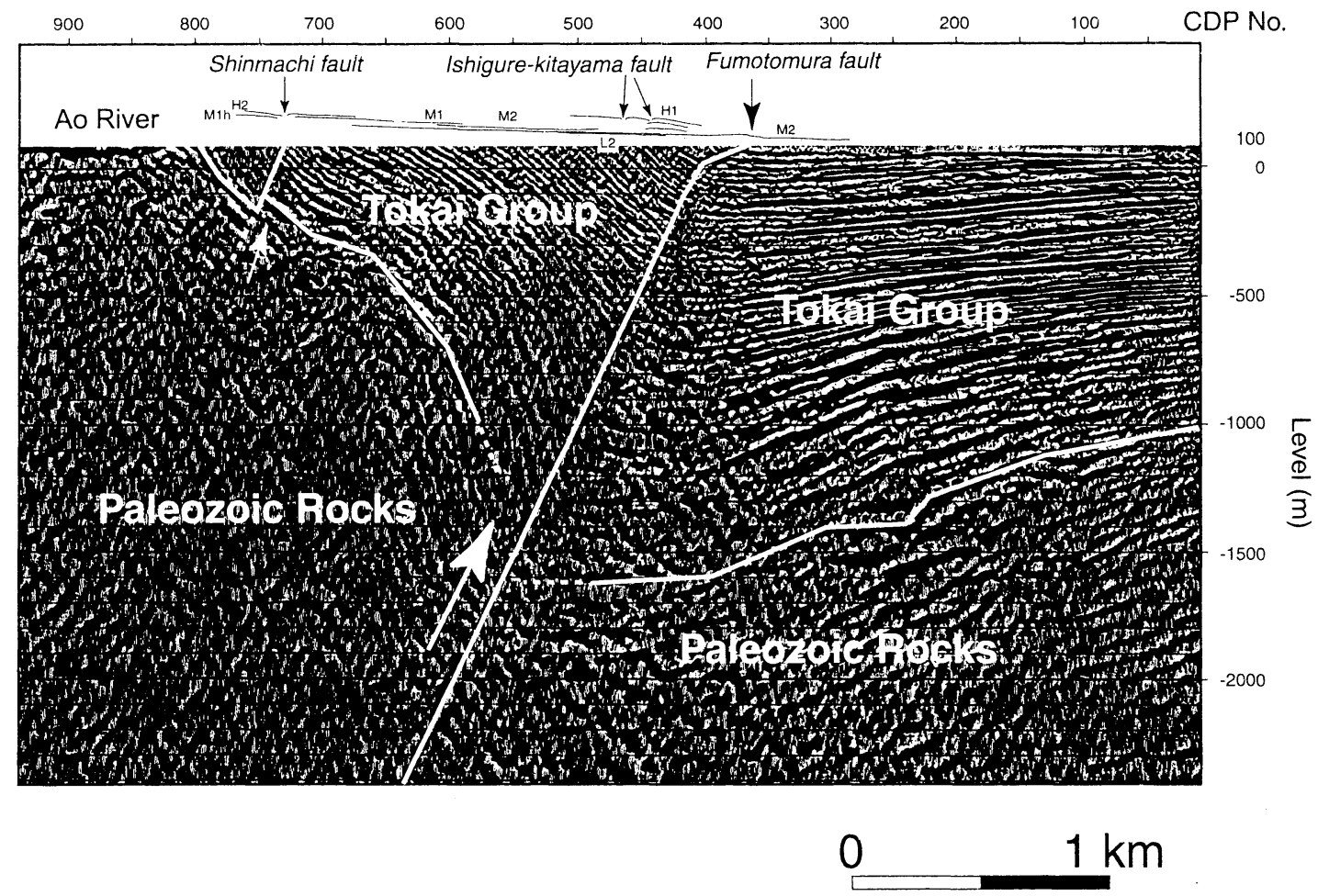

Fig. 9. Comparison of deformed terrace surfaces and the Tokai Group. Upper is longitudinal profile of Ao River (dashed line) and of terraces, and lower is the interpreted seismic reflection profile (migrated, depth). No vertical exaggeration. 
高位段丘面群は麓村断層の撓曲崖に向かって東に急傾斜 し, 低位・中位段丘面上には撓曲崖・低断層崖が形成さ れているが，そのほか副次的な断首によって変位を受け ている以外には段丘面の変形は認められない。 また，低 位段丘面は青川の河床綐断形とほぼ平行である。このよ うに，麓村断層の活動による段丘面の撓曲変形は断層を 挟んで東西約 $500 \mathrm{~m}$ の範囲にわたり, 単斜構造に比べ て狭い範囲に限られる.このことは, 段丘面が単斜構造 の成長を示すような変形を受けていないことを示す.

一方, 第四紀後期における麓村断層の平均上下変位 速度は $0.1 \sim 0.3 \mathrm{~mm} / \mathrm{yr}$ 程度とされる[太田・寒川 (1984), 東郷・岡田 (1989), 三重県地域活断層委員会 (1996)]. 一方, 前節で求めたように, 単斜構造の成長速 度は上下成分で $0.58 \sim 0.67 \mathrm{~mm} / \mathrm{yr}$ 以上, 水平成分で $0.30 \sim 0.37 \mathrm{~mm} / \mathrm{yr}$ 以上である.

単斜構造の成長速度と簏村断首の平均变位速度は, 異 なる地質時代に形成された变位基準をもとに求めたもの であるから, 両者を単純に比較することはできないが, 以下では鮮新世後期以降の地殼变動の一様性を仮定して 議論を進める.

単斜構造の成長が平面の断層面における断首運動に よって生じたと仮定すれば，断首面上のネットスリップ は $0.66 \sim 0.77 \mathrm{~mm} / \mathrm{yr}$ 以上, 断層面の傾斜は $57 \sim 66$ 度 である.

麓村断層の地表部における断首面の傾斜は露頭の観察 から 30 度程度である [東郷・岡田 (1989)] ので, 地表 部におけるネットスリップの上下成分は $0.36 \pm 0.03$ $\mathrm{mm} / \mathrm{yr}$ となり, 簏村断層の平均上下変位速度と同程度 の值になる.したがって, 単斜の成長が麓村断層の断層 運動によって形成されたと考えることが可能である.こ の場合, Fig. 9 は段丘面が形成された第四紀後期には変 形が断首近傍に局在化していることを意味する.このこ とは, 東海層群の単斜構造が形成された時期から第四紀 後期にかけて断層の先端が地表面に延伸したとする考え で説明できる. すなわち, 東海首群の単斜構造と段丘面 の局所的な撓曲変形は一種の fault-propagation fold に 伴うあのであると考えられる. 本地域と同様に第四紀後 期に变形が局在化することを指摘した例としては, 左内 堆積盆地東部の活襢曲 [小松原 (1998)］が挙げられる.

\section{§6. まとめと問題点}

反射断面とボーリングコアおよび表層地質の対比か ら，鈴鹿山脈東簏地域に単斜構造が存在することが明ら かになった. また, 東海層群が growth strata であるこ とと, 段丘面群と東海層群の変形域の比較から, 単斜構 造の発達過程および麓村断首の断層運動との関係を推定
した.

単斜構造の発現時期は東海層群が堆積を開始した 2.9 $\pm 0.2 \mathrm{Ma}$ 前後であると考えられる. 単斜構造の平均上 下落差速度は $0.58 \sim 0.67 \mathrm{~mm} / \mathrm{yr}$ 以上, 平均水平短縮速 度は $0.30 \sim 0.37 \mathrm{~mm} / \mathrm{yr}$ 以上である.この成長速度は地 形学的に求められた麓村断首の第四紀後期における平均 变位速度と同程度である. また, 鈴鹿山脈東簏部の単斜 構造・段丘面の変形は, fault-propagation fold に伴っ て生じた可能性がある.

また, 反射断面では藤原岳断層に伴う構造は認められ ず, 藤原岳断首は組織地形である可能性があることを指 摘した。 大規模かつ明瞭な地形境界である断層崖が，そ れに対応する地下構造を伴わないことは变動地形学上重 要な問題である.また, 藤原岳断層と同様に山地と丘陵 の地形境界部に位置する尾高断首は第四紀後期に活動的 であることから, 今回推定した地質構造が鈴鹿山脈東麓 部全域に当てはまるとは限らない，山脈東簏部の東海層 群の構造を確定するには, 更なる反射法地震探査・重力 探査等による地下構造データの蓄積を待つ必要があろ う.

\section{謝辞}

京都大学大学院理学研究科の堤 浩之助手には本研究 全般にわたり御指導をして頂いた. 愛知教育大学の戸田 茂助手には反射法地震探查について有益な御意見を頂い た. 地質調查所の吉田史郎氏には重要な露頭の位置を教 えて頂いた. 東京大学大学院理学研究科の池田安隆助教 授, 法政大学地学研究室の東郷正美教授をはじめとする 諸先生方には有益な御議論をして頂いた. 京都大学大学 院理学研究科の院生および学部生諸氏には貴重な御意見 を頂いた. また, 本稿の内容は查読者である寒川 旭氏と 佐藤比呂志氏の丁寧な御指摘により大幅に改善された。

末筆ながら, 上記の方々を含む, 本稿作成の過程でお 世話になった全ての方々に謝意を表します。

本稿は, 地球惑星科学関連学会 1998 年合同大会で発 表した内容を加筆・修正したあのである.

\section{文献}

秦 好利, 1967, 三重県荔野地方の新生代層, 資源総合 開発研究所研究報告, 4, 77-107.

原山 智・宮村 学・吉田史郎・三村弘二・栗本史雄, 1989 , 御在所山地域の地質, 地域地質研究報告 (5万 分の 1 地質図幅), 地質調查所, $145 \mathrm{p}$.

Huftile, G. J. and R.S. Yeats, 1995, Convergence rates across a displacement transfer zone in the western Transverse Ranges, Ventura Basin, California, J. Geophys. Res., 100, 2043-2067. 
Huzita, K., 1962, Tectonic development of the Median Zone (Setouchi) of Southwest Japan, since Miocene, J. Geosci., Osaka City Univ., 6, 103-144.

IKEDA, Y., 1983, Thrust-front migration and its mechanism: evolution of intraplate thrust fault systems, Bull. Dept. Geogr., Univ. Tokyo, 15, 125-159.

石山達也・堤 浩之・竹村恵二・岡田篤正, 1998, 鈴鹿 山脈東麓地域の第四紀における断層運動と地質構造の 関係, 地球惑星科学学会 1998 年関連合同大会予稿 集, 317 .

石山達也・竹村恵二・佃 栄吉・佐藤 努, 1999, 三重 県員弁郡北勢町麓村 $500 \mathrm{~m}$ ボーリングコアの岩相・ 火山灭層序，地調月報，投稿中.

片岡香子・吉川周作, 1997, 三重県鈴鹿川流域の段丘構 成層の層序・編年一火山灰稀産地域での段丘編年の試 み一，第四紀研究，36, 263-276.

活断層研究会, 1991, 新編日本の活断層一分布図と資 料一, 東京大学出版会, $437 \mathrm{pp}$.

木村一朗, 1971, 伊勢湾西岸地域の中位段丘,「竹原平 一教授記念論文集」, 1-12.

小松原 环, 1998, 庄内堆積盆地東部における伏在断層 の成長に伴う活褶曲の変形過程, 地学雑誌, 107,368389.

三重県地域活断首委員会, 1996 , 平成 7 年度地震調查研 究交付金・鈴鹿東縁断層系に関する調查成果報告書.

太田陽子・寒川 旭, 1984, 鈴鹿山脈東麓地域の変位地 形之第四紀地殻変動, 地理学評論, 57, 237-262.

佐藤 努・高橋 誠・佃 栄吉・上村 尚・菅原豊松, 1999, 鈴鹿東縁断層帯における地下水観測井の新設 一北勢観測井一，地調月報，投稿中.

Schneider, C. L., C. Hummon, R. Yeats and G. L. Huftile, 1996, Structural evolution of the northern Los Angels basin, California, based on growth strata, Tectonics, 15, 341-355.

Suppe, J., G. T. Сноu and S. C. Ноок, 1992, Rates of folding and faulting determined from growth strata, in Thrust Tectonics, ed. by K. R. McKlay, Chapman and Hall, London, 105-121.

鈴木康弘 - 千田 昇 - 渡辺満久 - 岡田篤正, 1996, 1: 25,000 都市圈活断層図『桑名』, 国土地理院技術資料 D. 1-No. 333.

武久義彦, 1979 , 鈴鹿山脈東麓の活断層, 奈良女子大学 地理学研究報告, 1, 119-138.

滝本 清, 1935, 三重県一志地方の新生界, 地球, 23, 6-18.

Takemura, K., 1985, The Plio-Pleistocene Tokai Group and the tectonic development around Ise Bay of Central Japan since Pliocene, Mem. Fac. Sci, Kyoto Univ, Ser. Geol. \& Mineral, 51(1 \& 2), 21-96.

竹村恵二・三重県地域活断層調查委員会 - 井川 猛 - 向 山 栄・松本俊幸・平野 昌・西口 輝, 1999, 鈴鹿 山脈東縁部の地下構造一反射法地震探査による解析, 第四紀研究, 投稿中.

東鄉正美・岡田篤正, 1989, 鈴鹿山地東麓・大安町にお ける一志断層系の性状, 活断層研究, 7, 71-81.

YEATS, R. S., 1986, Active faults related to folding, in Active tectonics, ed. by R. E. Wallace, National Academy Press, Washington, D. C., 63-79.

横山卓雄, 1971 , 鈴鹿山脈の形成 (その 1), 三重県員弁 郡の鮮新更新統を中心として, 竹原平一教授記念論文 集, 55-67.

横山卓雄・松田高明・竹村恵二, 1980, 東海層群の フィッション・トラック年代 (その 1), 第四紀研究, 19, 301-309.

吉田史郎, 1990, 東海層群の層序と東海湖盆の古地理変 遷, 地調月報, 41, 303-340.

吉田史郎・栗本史雄・宮村 学, 1991, 桑名地域の地 質, 地域地質研究報告 (5 万分の 1 地質図幅), 地質調 查所, 154 pp. 